\title{
FILOSOFAR ACADÊMICO E PENSAMENTO INSURGENTE (DIS-PENSANDO A FILOSOFIA A PARTIR DE OSWALD DE ANDRADE E RAUL SEIXAS)
}

\author{
Julio Cabrera'
}

RESUMO: Dentro de uma série de convicções básicas do atual filosofar acadêmico destacam-se duas características: a exigência de exaustividade e a exigência de frieza vital, que determinam que os trabalhos filosóficos sejam feitos com pleno conhecimento de fontes e de maneira objetiva e impessoal. $\mathrm{O}$ texto traz à tona dois escritores brasileiros que contestam essas exigências: Oswald de Andrade enfrenta a exigência de exaustividade com a sua ideia da antropofagia, e Raul Seixas a exigência de frieza vital através de um pensamento vivido na música e assumido na própria vida e morte. O texto defende que estas duas atitudes enfrentam uma situação atual de indústria cultural filosófica, numa tecnologia do paper erudito e sem autoralidade. Pensar contra essa tendência é um modo de dispensar o pensamento europeu, visto hoje não como modelo a seguir, mas como mero objeto de estudo.

PALAVRAS-CHAVE: Filosofar Acadêmico; Pensamento Insurgente; Oswald de Andrade; Raul Seixas.

ABSTRACT: Two features in the present academic philosophical practice are exhaustiveness and impersonality, demanding full 
knowledge of sources and anonymous styles of expositions. Two Brazilian writers challenge these academic demands: Oswald de Andrade faces the demand of exhaustiveness with his idea of anthropophagy; Raul Seixas does the same regarding the demand of impersonality, through the exercise of a philosophy intensely lived in a way of making music, living and dying. This article maintains that these two insurgent attitudes challenge a present situation of "philosophical cultural industry" centered upon the production of papers erudite and without existential involvement. Thinking against this hegemonic tendency means beginning to take European philosophy as a model for doing philosophy instead of a mere object for scholarly analysis.

KEYWORDS: Academic Philosophical Practice; Insurgent Thinking; Oswald de Andrade; Raul Seixas. 


\section{DUAS CARACTERÍSTICAS DO FILOSOFAR ACADÊMICO: EXAUSTIVIDADE E FRIEZA VITAL, DENTRO DO MARCO DO ACERVO T.}

Num texto anterior ${ }^{2}$, referi-me a um conjunto de convicções inabaláveis da nossa atual cultura filosófica institucionalizada. Chamei esse conjunto de "Acervo T". Neste novo texto pretendo referir-me a duas características mais específicas desse filosofar, que chamarei "exigência de exaustividade" e "exigência de frieza vital". Meu objetivo será mostrar como essas características mantêm a atividade filosófica latinoamericana (e brasileira em particular) na dependência de uma "Europa" mitificada, que funciona como modelo inibidor em lugar de dinamizador de atividades filosóficas criadoras. $\mathrm{O}$ texto pretende apontar para a obra de dois brasileiros natos e netos que desafiaram essas duas características dispensando - num sentido que será explicado - o pensamento filosófico hegemônico, em lugar de meramente pensá-lo.

Reapresento aqui rapidamente as ideias fundamentais do Acervo T. (Para mais detalhes, remeto o leitor ao artigo indicado na nota 1). Este conjunto de ideias possui todas as características do "vigente": são ideias aceitas por todos os membros da comunidade e que não se põem mais em discussão, teses que despertam a adesão imediata de qualquer público, ideias que já não são mais de ninguém e são de todos, e em cima das quais os membros da comunidade constroem as suas carreiras bem sucedidas e constituem seu prestígio. São também aquelas que determinam o "valor" ou "falta de valor" de um trabalho filosófico. Essas teses, ou convicções absolutas, são, basicamente, as seguintes: 
(1) A filosofia é universal; ela fala desde e com a universalidade da razão. Os problemas filosóficos surgem do próprio exercício dessa razão universal e atingem qualquer ser humano em qualquer lugar do planeta, precisamente pela sua natureza racional que fala ao humano enquanto tal, com independência de nacionalidades ou idiossincrasias regionais.

(2) A história da filosofia europeia, de Tales a Habermas, mostra de maneira exemplar e modelar esse exercício universal da razão.

(3) As filosofias de outros países, entre eles os latinoamericanos, não conseguiram, até hoje, atingir esse nível universal da razão; uma boa parcela do que se escreve fora de Europa (por exemplo, na América Latina) refere-se a motivos nacionais (ou mesmo nacionalistas), mais de interesse para uma "história das ideias" do que propriamente de interesse universal. É por isso que não existem grandes pensadores brasileiros, colombianos ou africanos sendo discutidos atualmente no mundo.

(4) Quando se fala de uma filosofia a partir de certa parte do planeta (por exemplo, desde o Brasil, ou desde os Estados Unidos ou desde a Bélgica) se alude ilegitimamente a uma origem "nacional" do filosofar, o que contradiz frontalmente a natureza universal da filosofia. Estes projetos "nacionais" não fazem o menor sentido e devem ser abandonados por não serem universais e, portanto, não filosóficos. Falar de uma filosofia latinoamericana ou brasileira seria tão absurdo como falar 
de uma física ou de uma matemática brasileiras ou norte-americanas. As alegações "nacionais" são mais políticas do que estritamente filosóficas.

(5) Quando essas filosofias nacionais se insurgem contra a filosofia universal europeia, elas mesmas já a utilizam para dirigir suas críticas; somos formados por categorias europeias de pensamento, de maneira que rebelar-se contra elas representa um gesto impossível e contraditório; o que prova que, pelo menos por enquanto, só existe filosofia europeia, ao ser ela indispensável mesmo para criticar a sua natureza e limites.

(6) Conhecer filosofia é, fundamentalmente, adquirir sólidos conhecimentos sobre história da filosofia europeia, para, a partir daí, estar devidamente capacitado para praticar exegeses, interpretações e estudos comparativos, que só podem ser efetuados a partir de um sólido conhecimento dessa história, visando preencher as condições para alguma futura contribuição significativa para a filosofia universal.

(7) Qualquer "filosofar autoral" que se pretenda assumir, pressupõe, como condição necessária, que se conheça solidamente esse acervo de conhecimentos filosóficos universais; qualquer tentativa de "filosofar autônomo" - ou, pior ainda, de "filosofar independente" - que prescinda desses conhecimentos, corre o lamentável risco de repetir o já dito, e de incorrer em todo tipo de ingenuidade. 
Denomino Acervo $\mathrm{T}$ ao conjunto (1)-(7) de convicções inabaláveis (mesmo que se discorde neste ou naquele termo da sua formulação) das nossas comunidades filosóficas ${ }^{3}$. No que tange às duas características mais específicas às quais vou me referir neste artigo - a "exigência de exaustividade" e "exigência de frieza vital" - elas estão diretamente ligadas com as características (6) e (7) do Acervo T, embora todas as outras características forneçam um pano de fundo daquelas exigências. Passo agora a tentar esclarecê-las.

Chamo de "exigência de exaustividade" nos estudos filosóficos a ideia seguinte: ao debruçar-nos sobre um autor para estudar seu pensamento, o pesquisador deve "conhecer" profundamente toda a obra do autor estudado; ou, se esta for muito volumosa, deve-se, pelo menos, ter um conhecimento global da mesma através do intenso uso de literatura secundária, além da leitura atenta de todos os textos originais disponíveis. O "leitor exaustivo" sempre teme que alguém da audiência formule alguma pergunta que aluda a uma leitura que ele não conseguiu fazer. Se não se trata de autor, mas de temática, também haverá a exigência de conhecer adequadamente toda a literatura considerada relevante pela comunidade a respeito do assunto tratado, o que costuma ser chamado de status questionis, do pé em que se encontram atualmente as discussões relevantes.

Digamos que alguém se debruce em cima da questão da "intencionalidade". Terá que dar pelo menos uma olhada em Brentano, Meinong e Husserl e seus comentadores (Dreyfuss, Olafson, Follesdal, Barry Smith), para depois revisar a copiosa literatura analítica sobre o assunto, que cresce diariamente; além de consultar alguns importantes clássicos (como Frege, 
Russell, Wittgenstein e Quine, especialmente pelas conexões da intencionalidade com questões de discurso indireto e atitudes proposicionais), terá que consultar, pelo menos, os trabalhos de Anscombe, Chomsky, Kripke, Kaplan, Putnam, Dummett, Chissholm, Burge, Fodor, Dretske, Grice, Dennett, Crane, Davidson, MacDowell, Churchland, Rosenthal, Millikan, McGinn, Peacocke, Chalmers, Neander, Block e Searle.

A "exigência da exaustividade" determina não ser possível, nem sério nem responsável, escrever sobre a questão da intencionalidade sem conhecer adequadamente toda a literatura relevante ${ }^{4}$. Entretanto, o motivo pelo qual esta exigência (inserida dentro do espírito do Acervo $T$, especialmente em seus pontos (6) e (7)) será aqui criticada, não se refere ao tamanho e duração da "leitura exaustiva". Depois de tudo, "grandes filósofos" europeus gastaram literalmente a totalidade de suas vidas perseguindo uma obsessão pessoal, algo que lhes interessava de maneira vital e que eles se colocaram como tarefa irrenunciável (a relação do singular com Deus em Kierkegaard, a crítica da forma intelectualista de pensar em Schopenhauer ou o pensamento heideggeriano sobre o esquecimento do ser). Não se trata, pois, do tempo gasto, mas da natureza do que é feito nesse tempo.

É típico da "exigência de exaustividade" que a etapa de leituras tenda ao infinito. Alguém que sofre de maneira direta esta exigência virá a público sempre com a amarga sensação de "não ter lido o suficiente". A pretensão de exaustividade é atormentadora e premente; exige a informação sem a qual não se terá nenhum direito a falar. "Conhecer" será condição necessária para qualquer empreitada sobre um autor ou uma temática. É também notável perceber, no começo de falas em 
congressos, que muitos conferencistas esclarecem o óbvio quando dizem: "Nesta comunicação não pretendo, de forma alguma, ser exaustivo". O curioso deste tipo de afirmação não é seu conteúdo, mas a inutilidade da sua expressão; pois dado o enorme quantum de informações hoje disponíveis sobre qualquer autor ou tema filosófico, essa frase esclarece o óbvio, pois é simplesmente impossível ser exaustivo. Esta declaração, inútil em si mesma, é, porém, reveladora do fato de ser, realmente, a exaustividade o que se almeja, e se claudica diante da sua lamentada impossibilidade. "Ter lido tudo" é a expectativa que assoma pelas frestas da declaração, perfeitamente supérflua - quase uma desculpa - de "não pretender ser exaustivo".

Resumindo esta primeira característica: na atual comunidade filosófica, avalia-se como grave deficiência - que retira respeito e reconhecimento - não ter todos os "conhecimentos" considerados relevantes ao assunto ou autor tratado. Não se trata, pois, de exigir uma exaustividade absoluta impossível, mas sim de uma exaustividade relativa ao que a comunidade considera relevante, e que já costuma abranger um conjunto imenso de referências, o que sugere uma espécie de tarefa interminável (sobretudo com os dispositivos de informação com os quais se conta atualmente).

Passo a tentar formular brevemente a "exigência de frieza vital". Filósofos europeus como Kierkegaard, Unamuno, Ortega y Gasset, Henri Bergson, Karl Jaspers e Albert Camus, entre outros e em registros diferentes, falaram da enorme importância de vincular, interna e firmemente, filosofia e vida, conhecimento e experiência; tornar pessoal e biográfica a tarefa filosófica, tirá-la do anonimato e transformá-la numa 
empreitada existencial, na qual a própria vida esteja envolvida naquilo que se tenta refletir. Pensar com as entranhas, com a pele, e não apenas com a cabeça, fazer valer uma profunda motivação pessoal no que está sendo abordado, de tal forma que o pensamento seja também existencialmente motivado, e não apenas produto de leituras ou conhecimentos adquiridos. Escrever em primeira pessoa, de maneira autoral, assinando embaixo, através de textos que não poderiam ter sido escritos por qualquer um.

Ora, a "exigência de frieza vital" na construção de um texto filosófico, vai precisamente em direção contrária ao pregado por estes pensadores: um filosofar profissional e rigoroso exige distanciamento e frieza, despersonalização e anonimato; qualquer envolvimento vital é considerado pouco sério e pouco profissional. A vida deve ficar do lado de fora, tudo aquilo que biograficamente nos leva a filosofar é visto como irrelevante, apenas importando os resultados obtidos pela força da razão em seu exercício universal e impessoal. (Um dos procedimentos mais típicos dos avaliadores e corretores de revistas especializadas de filosofia, especialmente em países latino-americanos, é trocar todas as expressões de primeira pessoa (do tipo "Eu penso que", "Parece-me que") por expressões escritas em terceira pessoa, ou em estilo genérico e impessoal).

Não quer isto dizer que emoções, sentimentos e pathé existenciais não possam ser abordados e tratados pela filosofia, como o foram, de fato, por muitos clássicos do pensamento europeu, desde, pelo menos, o Banquete de Platão, até as morais de sentimentos dos moralistas escoceses do século XVIII, passando pelo Tratado das Paixões de Spinoza, e 
chegando ao pensamento sobre essência e formas da simpatia de Max Scheler e o tema dos afetos existenciais em Heidegger e Sartre no século XX. A exigência refere-se mais ao procedimento ou metodologia de acesso a essas questões, não a seu conteúdo temático. Poder-se-ia discursar sobre afetos, mas de maneira distanciada e racional, num método que não se deixe arrebatar pelo que for abordado. Pode-se debater friamente sobre afetos quentes. (Vide, como exemplo típico, os artigos dos "especialistas em Nietzsche"; o filósofo das paixões avassaladoras fica encapsulado em rigorosos papers acadêmicos e submetido ao escrutínio mais desapaixonado).

A "exigência de exaustividade" refere-se mais à leitura daquele acervo filosófico venerável mencionado nos pontos (2) e (6) do Acervo $T$, enquanto que a "exigência de frieza vital" se refere mais à escrita de textos. Deve-se ler o mais exaustivamente possível, e deve-se escrever da maneira mais fria, objetiva e argumentativa possível. Juntando ambas as exigências, o filosofar oficial hoje imperante nas universidades recompensa trabalhadores filosóficos que observem ao pé da letra a exigência de exaustividade - na forma de uma sólida erudição - e a exigência de frieza vital, no sentido da impessoalidade típica da filosofia universal (tudo isto vinculado aos pontos (1), (3) e (4) do Acervo T).

Os professores de filosofia do século XXI, não demasiado diferentes daqueles criticados por Schopenhauer em seu famoso opúsculo sobre a filosofia universitária e outros escritos ${ }^{5}$, seguem regularmente o Acervo T, e, mais especificamente, as exigências de exaustividade e frieza vital. Textos filosóficos sem citações nem referências a autores, sem conhecimento 
erudito de fontes (em línguas originais se for o caso), e que sejam escritos em estilos autobiográficos e existenciais, seguindo as próprias intuições e tentando personalizar, são mal vistos, considerados trabalhos diletantes, improvisados, pré-profissionais e não argumentados, que não podem ser levados a sério ${ }^{6}$.

\section{OSWALD DE ANDRADE E RAUL SEIXAS COMO VIAS INSURGENTES CONTRA A EXAUSTIVIDADE E FRIEZA VITAL DA FILOSOFIA INSTITUCIONALIZADA}

Nesta seção, tento estudar formas de insurgência contra as exigências de exaustividade e de frieza vital, visando identificar e formular outras formas de relação com a filosofia europeia, diferentes das sugeridas pelo Acervo $\mathrm{T}$. Dou ao termo "insurgência" um sentido técnico, já aludido em outros escritos. Insurgência não aponta apenas para um ato "emancipador" ou rebelde que seria opcional, que poderia ou não acontecer. Insurgência, em meu sentido, não é apenas uma forma de fazer algo ou de ser algo, não uma questão de essência, mas uma forma de surgir, de vir a ser, uma questão de existência. Insurgir é a única maneira de surgir daquelas atividades ou produções que estão, por um motivo ou outro, impedidas de surgir, e que então surgem-contra, em oposição a, em luta contra aquilo que as impede de surgir, surgindo contra os valores vigentes e as comunidades hegemônicas.

Algumas produções filosóficas simplesmente surgem, pois se espera que elas apareçam e se faz de tudo para propiciá-las; 
FILOSOFAR ACADÊMICO E PENSAMENTO INSURGENTE: (DIS-PENSANDO A FILOSOFIA...

mas outras não têm permissão de existir, não se espera por elas, acha-se, inclusive, um atrevimento a sua intenção de vir a ser, e se coloca todo tipo de obstáculos - muitos deles já perfeitamente naturalizados - para que esse surgimento não se produza. Produções filosóficas nessa situação têm, pois, que surgir insurgindo-se contra o que as impede e bloqueia. Ou se insurgem ou não surgem de forma alguma; a insurgência é a sua única maneira de surgir num mundo onde o pensamento está cooptado pela ideologia do Acervo $\mathrm{T}$ e seus desdobramentos normativos.

É nesta trilha que quero introduzir aqui a noção de "dispensar" como, precisamente, uma forma insurgente de pensar, que, ao mesmo tempo, deixa de lado e cria. Aos que assim constroem seus pensamentos podemos chamar de "dispensadores". Assim como o pensador europeu Heidegger se indagou acerca do "que significa pensar", pensadores periféricos teriam que perguntar-se "o que significa dispensar". As noções de "insurgência" e de "dispensar" são complexas; no presente trabalho, pretendo apenas avançar uma primeira contribuição para esta temática ${ }^{7}$, me referindo à obra de dois pensadores brasileiros que praticaram ousadamente o exercício da dispensa; dois dispensadores, por conseguinte. O dispensar de um deles - o escritor paulista Oswald de Andrade - servirá aqui como instrumento insurgente contra a "exigência de exaustividade", enquanto que os dispensares do compositor baiano Raul Seixas são analisados como forma de insurgência contra a "exigência de frieza vital". Vou desenvolver seguidamente estes tópicos em detalhe. 


\subsection{OSWALD DE ANDRADE, DISPENSADOR DA EXAUSTIVIDADE}

\subsubsection{ANTROPOFAGIA: IDEIAS CENTRAIS}

A noção central do pensamento de Oswald de Andrade em relação ao tema da exaustividade é a noção de antropofagia. Ele expõe as suas ideias sobre este tópico em vários textos, especialmente no "Manifesto antropófago", de 1928, nos artigos "O antropófago", "Mensagem ao antropófago desconhecido" e "Um aspecto antropofágico da cultura brasileira", e na dissertação "A crise da filosofia messiânica" (1950). As ideias fundamentais são, na minha leitura, as cinco seguintes:

(a) A motivação mais profunda do pensamento antropofágico é a busca de uma igualdade e dignidade a respeito de Europa após a invasão, conquista e colonização, que nunca deixou de acontecer desde o século XV até os dias de hoje; (b) A cultura europeia é fundamentalmente messiânica, num sentido universalista, patriarcal e salvador; nós americanos somos a crise do messianismo europeu, e o que temos para opor ao messianismo é, precisamente, uma cultura antropófaga; (c) O objetivo primordial de igualdade e dignidade, e a acentuação da crise do messianismo, é perseguido segundo o modelo indígena do devorar ritual do inimigo, profundamente diferente de toda forma de canibalismo; (d) Estes elementos do universo cultural indígena se encontram, numa composição complexa, com uma tecnologia de ponta, o que dá como resultado um "primitivismo tecnologizado", sem volta nostálgica ao passado mas sem esquecimento da situação de submissão 
FILOSOFAR ACADÊMICO E PENSAMENTO INSURGENTE: (DIS-PENSANDO A FILOSOFIA...

e necessidade de revolta; (e) Esta revolução cultural dáse também no nível do estilo e da linguagem, na forma de textos (fundamentalmente escritos, mas também postos em imagens, nas artes plásticas e no cinema). Vou comentar brevemente cada uma destas temáticas.

(a). Busca de uma igualdade. O objetivo primordial da filosofia oswaldiana é explorar uma possível reconquista de relações igualitárias com Europa, não no nível patriarcal do pacto cultural produtivo (estratégia de poder do europeu para não ter que interagir com seus submetidos), mas em termos de assimilação e apropriação. Muito antes da literatura de-colonial, Oswald já escrevia: “...particularmente em América se produziu o fenômeno da subversão de valores nativos pela colonização brutal e desfrutadora (...)”. Os jesuítas impingiram o cristianismo nos indígenas “...fazendo traduzir para a língua tupi os mandamentos da Lei de Deus. Não tomando o menor conhecimento da vida e dos costumes dos indígenas...". "Foi uma obra de mísera coação a chamada 'Conquista espiritual' dos inacianos'. Aqui, no Brasil, nos vimos forçados a suar sobre a terra, escravos e colonizadores, para fornecer recursos à Europa, cuja Revolução Industrial se alimentava do lastro de nossos metais preciosos" ("O antropófago", Em: Estética e Política (EP), p. 444-445).

(b) Rejeição do messiânico. Oswald viu América como a crise de uma Europa messiânica, como a queda de seus absolutismos filosóficos e políticos, a evidência de que havia o Outro, de que a cultura europeia era apenas uma entre muitas. O primeiro grande impacto de América em Europa foi a espantosa constatação de que o seu Cristo universal, que "fala a todos os homens", não era conhecido nas novas 
terras. A Bíblia “...viu-se de um momento a outro, refutada na sua pobre geografia judaica, na sua triste etnologia racista e, sobretudo, na suposta vigilância que havia presidido imemorialmente as relações do criador com a criatura. Como poderia se explicar o abandono de uma humanidade inteira por parte do rancoroso e ortodoxo inventor de Decálogo? (EP, p. 399). "Havia sido encontrada uma parte do gênero humano completamente desguarnecida das leis e preconceitos que haviam regido toda a Idade Média" (400). América era a constatação da falência do messianismo cristão pretensamente "universal", o que obrigava a lançar mão de todo tipo de recursos argumentativos e retóricos para tentar explicar por que os indígenas americanos nunca tinham recebido a "Boa Nova".

No ensaio "Mensagem ao antropófago desconhecido", coletado no mesmo livro, Oswald caracteriza sinteticamente o messianismo em contraposição à cultura antropofágica: “...as civilizações que admitem uma concepção messiânica da vida, fazendo o indivíduo objeto de graça, de eleição, de imortalidade e de sobrevivência, se dessolidarizam, produzindo o egotismo do mundo contemporâneo" (EP, p. 453). O mundo do "homem civilizado" tende a ser messiânico, enquanto o do homem primitivo é antropofágico ("A crise da filosofia messiânica", em: A Utopia antropofágica (UA), p. 102). No mundo civilizado, depois que os homens começaram a escravizar outros homens, em lugar de devorá-los como na etapa primitiva, o messianismo se torna indispensável: "Sem a ideia de uma vida futura, seria difícil ao homem suportar a sua condição de escravo. Daí a importância do messianismo..." (UA, p. 104). 
A longa dissertação "A crise da filosofia messiânica" visa mostrar a vigência do messianismo ao longo de toda historia do pensamento ocidental (UA, pp. 105-125) e a sua atual crise, já começada nos séculos XVI e XVII, quando o progresso das ciências projetava explicar com sucesso aquilo que as religiões não conseguiram entender (p. 126). $\mathrm{O}$ dinheiro começa a mostrar seu imenso poder aglutinador (127) e nasce o individualismo moderno, tornando a casta sacerdotal dispensável ("Qualquer mortal faz suas contas com o próprio Deus”, p. 131). Mas com Karl Marx ameaça instaurar-se um novo tipo de messianismo, agora leigo e guiado pelas leis da Economia política (135-36). "Quem poderia prever, quem ousaria sonhar que o Messianismo em que se bipartiu a religião de Cristo (Reforma e ContraReforma) iria medrar no terreno sáfaro das reivindicações materialistas do marxismo?” (p. 138).

O messianismo representa uma tentação irresistível do mundo branco civilizado e vestido; mesmo em seus mais ferrenhos críticos do século XX, como o Existencialismo, assoma a tentação messiânica: "O que se tenta pelas formas audazes ou dissimuladas da filosofia contemporânea é restaurar, através do existencialismo, da axiologia, da fenomenologia e mesmo do marxismo-leninismo, o Ser como tal em seu trono absolutista" (p. 141). Mas é, em todo caso, o Existencialismo, quando liberado da Fenomenologia, a corrente que melhor pode apontar para a efetiva superação do messianismo: "O Existencialismo recolocou o homem na sua ansiedade ancestral. E isso basta. Tanto a equação Tempo e Ser, o estar para a morte, o naufrágio de Jaspers como a tensão de Sartre ante a Negatividade, tudo recoloca o homem no 
meridiano da devoração" (p. 142). Poderia o Existencialismo pensar-se como uma filosofia europeia devorada, como um tentáculo tardio da influência de América no universo de ideias europeu? ${ }^{\text {. }}$

(c) Antropofagia e canibalismo. No famoso "Manifesto antropófago", Oswald exprime em forma de aforismos contundentes e sibilinos alguns dos traços conspícuos da visão antropófaga do mundo. A declaração "Só a antropofagia nos une" (UA, p. 47) já aponta para a insurgência, pois o "nos" sugere que a antropofagia é uma postura assumida contra a dominação. Outras afirmações cruciais do Manifesto: "Contra todas as catequeses", "Só me interessa o que não é meu. Lei do homem. Lei do antropófago", "A reação contra o homem vestido", “(..) nunca tivemos gramáticas...” (p. 47), "Sem nós a Europa não teria sequer a sua pobre declaração dos direitos do homem", "Nunca fomos catequizados", “(..) nunca admitimos o nascimento da lógica entre nós” (p. 48), "Mas não foram cruzados os que vieram. Foram fugitivos de uma civilização que estamos comendo (...)", "Não tivemos especulação. Mas tivemos adivinhação" (p. 50), "Antropofagia. Absorção do inimigo sacro. Para transformá-lo em totem" (p. 51), "A nossa independência ainda não foi proclamada" (p. 52).

Em "Mensagem ao antropófago desconhecido", Oswald escreve: "Um passo além de Sartre e de Camus. A antropofagia" (EP, p. 447). Chama as filosofias europeias de "filosofias do homem vestido" e proclama: "É preciso ouvir o homem nu". "A 'vida autêntica' de Heidegger é a vida do antropófago que resiste no homem vestido" (p. 448). "Nada existe fora da Devoração. O ser é a Devoração pura e eterna. 
FILOSOFAR ACADÊMICO E PENSAMENTO INSURGENTE: (DIS-PENSANDO A FILOSOFIA...

O homem nu compreenderá" (p. 449). Em "Um aspecto antropofágico da cultura brasileira...", escreve que a cultura primitiva "Compreende a vida como devoração e a simboliza no rito antropofágico, que é comunhão" (EP, p. 453). Em "O antropófago" louva Montaigne pelo seu famoso ensaio sobre os canibais, um século anterior à Revolução Francesa, já determinando "...as linhas mestras da humanidade futura" e “...todo estatuto das liberdades humanas..." (EP, p. 404).

No começo de "A crise da filosofia messiânica", Oswald apresenta de maneira mais clara a ideia da antropofagia ritual, elemento cultural de uma série de povos avançados que comiam carne humana como uma forma de "...exprimir um modo de pensar, uma visão do mundo...Contrapõe-se em seu sentido harmônico e comunial ao canibalismo que vem a ser a antropofagia por gula e também a antropofagia por fome..." (UA, p. 101).

(d) Primitivismo tecnologizado, sem volta ao passado e sem esquecimento. Já no "Manifesto antropófago", Oswald menciona o "bárbaro tecnizado de Keyserling" (UA, p.48). Em "A crise da filosofia messiânica", ele se utiliza de uma tríade que é ela mesma uma deslavada devoração de Hegel: tese, o homem natural; antítese, o homem civilizado; síntese, o homem natural tecnizado (UA, p. 103). O homem natural é canibal, guloso e agressivo; o homem civilizado é a tentativa de negação e superação do dado natural através do trabalho imemorial do espírito. O antropófago-síntese continua comendo humanos, não por fome ou canibalismo, mas ritualmente, incluindo hoje em dia, nesse ritual, a mais avançada tecnologia. O devorar foi modernizado. 
(e) Revolução textual. A antropofagia não apenas se "proclama" em manifestos; ela se inscreve, põe um registro, se instala numa forma de escrita que Oswald cultivou fartamente, tanto no estilo aforístico de seus Manifestos quanto em sua poesia política Pau Brasil, quanto, inclusive, em seus escritos mais filosóficos ("A crise..." e "A marcha das utopias"), onde o estilo narrativo e associativo é predominante, o que não lhe foi perdoado pela Academia de seu tempo, e menos ainda pela atual, onde os estilos expositivos de pensamentos filosóficos continuam sutilmente censurados, uma vez levantadas todas as censuras temáticas.

\subsubsection{PARA UMA ANTROPOFAGIA INTELECTUAL: LER, DIGERIR, EXPULSAR}

Tratar-se-ia agora de tentar inserir estas ideais oswaldianas - reunidas em (a)-(e) - no âmbito das atividades filosóficas, tentando pensar uma filosofia antropofágica que, seguindo cada um dos cinco pontos, deveria ser: um pensamento igualizante, não messiânico, antropófago, primitivomoderno e expresso em textos desregrados para os critérios vigentes. Aqui vou me centrar na questão (c), a antropofagia propriamente. Ela é extraordinariamente complexa, à qual se dedicaram muitos talentosos antropólogos; mesmo eles se depararam com todo tipo de fenômenos paradoxais e muito difíceis de interpretar. Tampouco é assunto homogêneo entre as diversas culturas indígenas, que apresentam muitas versões diferentes do antropofágico. Não posso aqui, pois, fazer outra coisa a não ser selecionar e comentar alguns poucos elementos relevantes para a nossa questão. 
FILOSOFAR ACADÊMICO E PENSAMENTO INSURGENTE: (DIS-PENSANDO A FILOSOFIA...

Em primeiro lugar, gostaria de mencionar o caráter ritual do devorar em geral, tanto de animais como de humanos, sendo que a linha demarcatória entre ambos, em muitas culturas indígenas, não é nítida. (Nem mesmo quando um indígena come literalmente pedaços de outro humano, não é certo, segundo seus parâmetros, que ele esteja realmente comendo um humano, nem mesmo que ele seja um humano; por outro lado, tigres e serpentes não estão isentos de serem vistos como humanos em determinadas situações). O devorar é realizado dentro de um cerimonial carregado de simbolismo, pleno de preparativos e consequências; constitui um ritual agonístico e cheio de sentido. Em segundo lugar, o devorar não é forçosamente agressivo ou destrutivo, produto do ódio, já que a vítima ou o inimigo é respeitado e admirado, reconhece-se seu saber e força e devorá-lo consiste, entre outras coisas, em apropriar-se dessas qualidades. Muitos estudiosos, porém, apontam para o caráter de vingança do ato antropofágico em muitos casos, onde a vítima era morta por ela ter matado antepassados ou membros importantes do próprio grupo. Mas mesmo que o motivo for a vingança, a morte do inimigo segue um ritual; nunca é simples assassinato.

Terceiro, devorar o inimigo era também, em muitos grupos indígenas, uma maneira de ter acesso a seu ponto de vista, à sua perspectiva. Este é um ponto bastante estudado por Eduardo Viveiros de Castro em vários de seus artigos 9 . Falando especificamente do canibalismo tupi, Viveiros escreve: "Minha análise deste complexo terminou por definilo como um processo de transmutação de perspectivas, onde o devorador assume o ponto de vista do devorado, e o devorado, o do devorador (...) o quê, do inimigo, era realmente devorado?(...) 
O canibalismo, e o tipo de guerra indígena a ele associado, implicaria (...) um movimento fundamental de assunção do ponto de vista do inimigo" (Viveiros de Castro E, "Xamanismo e sacrifício", em: A Inconstância da alma selvagem, p. 462).

Outro elemento importante da antropofagia era o prestígio social do qual se beneficiavam aqueles que tinham capturado um inimigo, ocupando depois lugares de honra dentro do ritual da devoração do prisioneiro. Também particularmente interessante era a ideia de que, quando um indígena estava doente e sem cura, a sua morte e devoração por parte da família podia considerar-se como uma forma de salvá-lo de uma morte longa, dolorosa e humilhante, ao tempo que os familiares se transformavam em lugares onde os restos do morto estariam melhor guardados do que na terra. Era uma maneira nobre de enterrá-los.

$\mathrm{O}$ que me interessa aqui de todos estes elementos, para uma filosofia antropofágica - e particularmente para uma teoria da leitura de textos filosóficos - é o caráter rigorosamente não exaustivo e eminentemente seletivo do processo antropófago. Na devoração ritual do inimigo, do conquistador e colonizador, fosse ou não por vingança, a vítima nunca era devorada por inteiro; tratava-se sempre de devorar pedaços ou membros, nunca o corpo todo, sempre deixando algo de lado. Do inimigo jamais importam todas as partes, mas apenas algumas; o resto se cospe ou joga fora. Isto aponta para algo profundo: o que resta do corpo não comido faz parte da cerimônia; não é puro resíduo, mas constitui contraponto essencial daquilo que foi efetivamente devorado. Temos que pensar como seria uma leitura antropofágica de textos filosóficos baseada nestes parâmetros. 
As ideias-mestras poderiam ser as seguintes: a leitura de filósofos deveria ser, em primeiro lugar, ritualizada, retirada de sua habitual arbitrariedade e aleatoriedade, não apenas guiada - como habitualmente - pela curiosidade ou avidez. Em segundo lugar, ela deveria ser feita com o intuito de absorver a coragem intelectual do autor, de aproveitá-lo em seu valor de saber filosófico num tipo de leitura que o matasse, que o suprimisse ou sacrificasse, mas com benefício e prazer intelectual. Em terceiro lugar, deveria ser uma leitura que se esforçasse maximamente por entender o ponto de vista do autor devorado sem tentar destruí-lo ou cultuá-lo, adquirindo a capacidade de ir desde seu ponto de vista ao nosso num fluxo dinâmico e múltiplo. Finalmente, o prestígio desta leitura surgiria deste matar o autor lido, transformandose o leitor antropófago em guardião das ideias que matou e devorou.

Este novo tipo de leitura filosófica seria profundamente estranho às nossas práticas, pois se opõe frontalmente ao modo habitual de ler filosofia, uma maneira consumista, cumulativa e exibida, ao mesmo tempo submissa e agressiva; leitura preocupada em sugar do autor as informações que mais despertem "interesse" e curiosidade intelectual dentro do jogo de ideias, em juntar a maior quantidade possível dessas informações e mostrá-las num jogo de citações e referências infindáveis, que constantemente interrompem o próprio pensamento; mais preocupada em contestar ou refutar ideias do que em entender o ponto de vista do autor, mas, ao mesmo tempo, sempre resguardando o autor refutado como objeto de culto intelectual, como se o "clássico" já crivado de críticas - tal como aquele gigante que ganhava mais força ao 
cair no chão - se tornasse mais e mais forte e hegemônico ao calor das contestações. O consumismo agressivo-cultual, tipicamente canibal, rege-se invariavelmente pela "exigência de exaustividade", enquanto que a leitura antropófaga de textos vive de seu caráter fragmentário e parcial, espelhando a essencial incompletude do humano.

De Oswald de Andrade interessam aqui os elementos capazes de enfrentar e destruir a ideia atual do que deva ser uma "formação" filosófica, com as suas ideias de erudição, conhecimento do status questionis, "competência na área" e noções correlatas. O processo seletivo é aqui fundamental, como "recusa ao todo"; o aproveitamento do alimento deriva da capacidade de saber selecionar e dispensar, guiada por um projeto filosófico que deveria sempre ser mais forte, persistente e obsessivo que qualquer programa "atualizado" de leituras. Não se trata, pois, de canibalismo intelectual ou de gula erudita, mas de alimentação cuidadosa e balanceada, onde o que se deixa de lado é tão importante quanto o que se consome. A nossa atual cultura filosófica é norteada pela ansiedade canibal, num desespero por livros, artigos e informações. Não há nada de ritual nessas práticas, nenhuma ideia profunda de assimilação; apenas a satisfação frustrante de um instinto primário que, segundo as inexoráveis leis do desejo, será seguida do mais insuportável tédio.

Contra isso, propõe-se uma leitura antropofágica, antológica (não ontológica), um pensar coletâneo. Esta leitura seletiva pode ser enormemente trabalhosa, esforçada, demorada e sofrida; pode levar uma vida inteira de reflexão. Apesar do estilo expositivo oswaldiano, livre, irônico e humorístico, não se deveria pensar na leitura antropófaga de 
autores como algo frívolo, fácil ou sumário. Pelo contrário, o processo de seleção dos pedaços adequados a uma leitura ritualizada e sistemática de autores não conta com nenhum dos automatismos e rotinas exegéticas sobre os quais os comentadores podem erguer rapidamente um forte prestígio acadêmico, sem necessidade de gerar grandes pensamentos.

Como deveríamos ler, por exemplo, Heidegger num viés antropófago? Em primeiro lugar, não deveríamos lê-lo bem, de maneira fiel e minuciosa, nem tampouco relê-lo tantas vezes quanto for necessário para apreender seu pensamento fora de um projeto firme de leitura que, inevitavelmente, o arrancará de seu próprio universo e o fará interagir com o nosso. Não lêlo tampouco de maneira "confiável", de forma tal que outros possam estudar o pensamento de Heidegger através de nosso texto. Não deveríamos encorajar leituras eruditas ou estudos apurados, não deveria haver nada de "pedagógico" em nossos textos antropofágicos. Deveríamos comer Heidegger por pedaços, tirar os mais gostosos de acordo com os próprios projetos e expectativas e sem qualquer compromisso de ter de acompanhá-lo até o fim em seu próprio percurso digestivo, em sua própria maneira de comer.

(Heidegger mesmo foi extremamente antropófago, seletivo e antológico em seus ensaios sobre Anaximandro, Platão, Kant, Duns Scotus e Hegel. Se houve um pensador que selecionou de todos os autores que leu apenas aquilo que lhe interessava, sem qualquer intuito exegético fiel, esse foi Heidegger, o mais oswaldiano dos filósofos alemães. "Kant e o problema da metafísica" é uma obra-prima de devoração intelectual, onde nas páginas finais ficamos com as pernas e os braços de Kant sobre a mesa depois de ter digerido o resto). 
Tampouco se precisa, na concepção antropófaga, ficar "citando" Heidegger, nem dizendo a cada instante "segundo Heidegger", "na concepção de Heidegger", e esses problemas de estilo que tanto atormentam aos comentadores e autores de teses. Na verdade, o leitor deveria descobrir por si só que se trata de um texto onde Heidegger tem "tudo a ver". Ele poderia nem sequer ser mencionado. Assimilação total. Mencionar e citar o autor lido ainda aponta para uma assimilação mal feita, para um distanciamento ansioso e referencial, para uma refeição forçada e sem gosto. Não mencionar o autor tratado mas transitar seu universo, respirar em sua atmosfera. Heidegger (no caso) deveria ser ator num palco novo onde jamais os "especialistas em Heidegger" poderiam descobri$10^{10}$.

Devorar Heidegger seria ritualizar a sua leitura visando a sua eliminação proveitosa; nada de respeito sacro pelos seus textos, mas a sua rigorosa e motivada destruição dentro de um projeto próprio de leitura (É assim que Enrique Dussel, por exemplo, destrói Heidegger dentro da sua filosofia, até torna-lo irreconhecível para seus devotos). Heidegger deve morrer dentro da cerimônia da nossa própria formação filosófica singular. Mas o nosso devorar Heidegger deveria ser uma constante e compreensiva oscilação entre a perspectiva heideggeriana e a nossa (assim como o indígena assumia às vezes a perspectiva do inimigo). Tampouco há por que excluir de nossa leitura de Heidegger (e dos filósofos europeus em geral) um forte elemento de vingança, pelo fato dos europeus terem assassinado nossos antepassados e substituído as nossas culturas. Um ódio sereno e motivado pelo autor lido é inteiramente saudável numa leitura antropófaga de autores. 
Numa sociedade filosófica antropófaga, o nosso prestígio como pesquisadores aumentará na medida em que tenhamos destruído mais pensadores europeus em benefício do nosso próprio florescimento intelectual, e não, como na situação atual, porque sabemos muito alemão e conhecemos a obra completa de Heidegger texto por texto. Mas também somos cientes de que, precisamente por tê-lo destruído, esse autor nos pertence, faz parte agora do nosso próprio corpo filosófico. Mesmo que tenhamos lido Heidegger com o ódio da vingança e com certo desprezo intelectual (e talvez pessoal, por seu envolvimento com o Nazismo, por exemplo), ainda assim Heidegger (e antes dele Nietzsche, e antes dele Kierkegaard e antes dele Schopenhauer) valeu certamente a pena de ser devorado, pois ele foi alguém que teve a coragem de pensar com a sua cabeça; ao devorá-lo, absorvemos essa coragem e a incorporamos em nosso próprio histórico filosófico. Pelo contrário, ler muita literatura secundária, escrita por espíritos medíocres e covardes, por aqueles que não se atreveram a pensar eclipsados pelos "grandes filosóficos", ler essa gente não nos faz crescer, não nos alimenta nem melhora; pelo contrário nos tornam covardes como eles. Ler pensamentos de segunda mão é como comer comida requentada.

Mas antropofagia é também rejeição, deixar de lado. Incorporar é apenas parte do processo; também expelimos e desincorporamos. Só perguntamos como assimilar Heidegger, mas nunca como expulsá-lo, como livrar-nos dele de vez. De certa forma, o que escrevemos sobre os europeus que comemos é a nossa expulsão, o que fizemos com eles nas nossas próprias entranhas transformadas. Oswald frisa o que fica em nós quando comemos o conquistador, o que foi 
incorporado em nossas células e sangue e nos fortalece; mas ele esquece dos resíduos, do elemento fecal da cultura, do que jogamos fora sem volta nem proveito. É o corpo que come, sem corpo não há antropofagia; mas o corpo também expele, já desde o suor e as lágrimas até outras excrescências menos nobres. Na culta Europa, claro, não há categorias filosóficas para isso (Podemos imaginar um refinado filósofo britânico falando dessas coisas? $)^{11}$

Quero acabar esta exposição sobre Oswald dizendo que ela mesma é antropófaga, propositalmente não exaustiva. Deixei de lado uma série de elementos - tais como, por exemplo, as questões ligadas com patriarcado e matriarcado - que não me interessaram e que os "especialistas em Oswald de Andrade" considerariam "absolutamente essenciais" e "indispensáveis para entender em profundidade o pensamento de Oswald de Andrade", precisamente o tipo de declaração e de atitude que Oswald mais abominava.

\subsection{RAUL SEIXAS, DISPENSADOR DA FRIEZA VITAL DO PENSAMENTO E CONSUMAÇÃO EXISTENCIAL DA FILOSOFIA}

Não é algo inédito que Raul Seixas apareça num escrito acadêmico. "Nos meios acadêmicos, a sua obra vem ganhando atenção crescente desde o final dos anos 1990, com a produção de monografias de graduação, dissertações de mestrado $e$ teses de doutorado" (ABONÍZIO e TEIXEIRA, Raul Seixas. Estudos interdisciplinares, p. 8). A bibliografia sobre o compositor baiano tem aumentado consideravelmente nas últimas décadas. Muitas dessas obras insistem bastante nos 
FILOSOFAR ACADÊMICO E PENSAMENTO INSURGENTE: (DIS-PENSANDO A FILOSOFIA...

aspectos biográficos e históricos. Aqueles que se debruçam especificamente sobre seu pensamento filosófico têm focado sobretudo as letras de algumas de suas canções. Meu acesso pretende ser um pouco diferente. Seixas me interessa, muito especificamente, como a realização plena da ideia de Ortega y Gasset, Unamuno e Camus, e outros pensadores citados no início deste trabalho, de que o pensamento filosófico deve ser feito de carne e sangue e não apenas exposto em escritos reproduzíveis. Seixas representa aqui a mais plena corporização do pensamento filosófico, a sua mais extrema materialização numa forma de viver e de morrer.

Desde criança e adolescente, Seixas já se preocupava obsessivamente com questões filosóficas primordiais: " $O$ que me preocupava mesmo eram os problemas da vida e da morte, o problema do homem, de onde vim, para onde vou, o que é que estou fazendo aqui" (Raul Seixas por ele mesmo (RS), p. 13). Tinha de início uma visão pessimista da vida, sem saber ainda o que esta palavra significava. Mais tarde, ele estuda formalmente filosofia na Universidade e se forma como professor de filosofia e psicologia. Na verdade, ele relata que namorava uma menina cujo pai, pastor protestante, não queria que sua filha casasse com alguém sem estudos. "Então queimei as pestanas e fiz vestibular para Direito, Filosofia e Psicologia. Passei em tudo, cheguei para o pai dela e disse: 'Viu como é fácil ser burro?"” (p. 128, p. 145). Ainda escreveu: "Eu que estudei história, filosofia, literatura, latim, tenho algo a dizer (...) Estudo o esoterismo, suas práticas e métodos, a antipsicanálise e faço minhas pesquisas...Para isso foi preciso um fácil diploma de professor de filosofia..." (p. 57). 
Várias vezes em escritos e entrevistas, Seixas refere-se a esta motivação filosófica fundamental: "Eu sou muito dado a filosofias, estudei muito filosofia, principalmente a metafísica, ontologia, essa coisa toda. Minha infância foi formada por, vamos dizer, um pessimismo incrivel, de Augusto dos Anjos, de Kafka, Schopenhauer" (86). Ficou muito impressionado com textos de Platão, Montaigne, Spinoza, Schopenhauer e Nietzsche, entre outros. Vemos aqui uma primeira ideia importante, uma dicotomia fundamental que Seixas estabelece entre os estudos filosóficos acadêmicos, que não valem muito, e as próprias indagações filosóficas, que são o que realmente importa. As respostas (ou, como veremos, a falta de respostas) às questões filosóficas fundamentais da vida, da morte e do destino humano não podem ser achadas nas universidades, mas na vida mesma. Isto significa que nem mesmo os "existencialismos" acadêmicos conseguirão agarrar realmente os problemas da vida, pois estes não se deixam captar por conceitos, mas por formas de vida que se deve assumir, algo vedado ao professor de filosofia, que fica afundado em seus meros conhecimentos "sobre" a vida.

Uma segunda questão fundamental na trajetória filosófica de Seixas é que ele inicialmente queria ser um escritor; a música não estava em seus planos. "O que eu queria mesmo era ser escritor. (...) Música, até o rock me pegar, era uma coisa bem secundária. Não que eu não gostasse. Mas era uma coisa intuitiva, e eu só cantava o que me entrava no ouvido, não me preocupava em saber, procurar letra para aprender, nunca fui fã. Apenas cantava" (p. 13). "Antes de vir pro Rio eu pensava em ser escritor. Eu sempre escrevi. Antes de cantar, pensei em escrever. Eu tenho alguma coisa escrita guardada no baú, que 
FILOSOFAR ACADÊMICO E PENSAMENTO INSURGENTE: (DIS-PENSANDO A FILOSOFIA...

penso publicar algum dia" (p. 86). Mais especificamente, seu propósito fundamental era escrever um tratado de metafísica. (p. 19). "Eu queria ser um escritor, feito Jorge Amado, vivendo de meus livros, escrevendo o dia todo, com uma camisa branca aberta no peito e um cigarro caindo do lado. Ou então fazer um tratado de metafísica. Porque eram essas coisas que sempre me incomodaram, me preocuparam; o problema da vida, do homem no universo..." (p. 43).

Temos então dois momentos: primeiro, a indagação filosófica pessoal que se desfaz de todo e qualquer fácil filosofar acadêmico; segundo, seu propósito primeiro de escrever seus pensamentos filosóficos. O terceiro momento é constituído pela música, que no início não se apresentava como fim em si mesmo, mas como uma maneira entre outras de transmitir aquelas ideias filosóficas que não mais iriam ser estampadas no papel. "...eu desisti de vez do livro que eu ia fazer, o tratado de metafísica. Decidi chegar ao livro através dos discos, dos sulcos, das rádios" (RS, p. 27). "Aí tem nego que diz: 'Você é um escritor, suas ideias são muito mais avançadas do que sua música'. E eu digo: 'Que loucura, não tem comparação, é um absurdo traçar um paralelo desses'. Eu gosto é desse cumpá-cum-cum, e é a única coisa que eu sei fazer, se adapta exatamente. Eu consigo escrever meu livro colocando dentro dessa música, desse ritmo tribal, porque o que eu falo é tribal" (p. 28).

Esta ideia é fundamental para o presente trabalho, pelo qual vale a pena insistir mais tempo nela. Seixas fala aqui da influência decisiva dos Beatles. "Foi quando eles chegaram cantando suas próprias músicas que eu vi que podia fazer o mesmo, dizer o que penso com minhas músicas. Foi ai que eu 
comecei a compor" (RS, pp. 44-45). "Em 'Ouro de tolo' existe um momento, aquele momento em que eu cheguei de Salvador cheio de preocupações metafísicas. Eu tinha me formado em professor de filosofia e dai fiz 'Ouro de tolo', 'A mosca na sopa', 'Metamorfose ambulante'..." (p. 112-113). Ele refere-se à sua própria geração como a "geração-sanduíche", que "segurou a barra sartreana toda" $(113,117)$. Falando de Elvis Presley, ele disse: "Estudei filosofia e tenho uma visão panorâmica das coisas que se passam no mundo, ele também tinha essa visão. Era muito mais do que intérprete" (126). "Todos meus trabalhos são feitos dentro de uma perspectiva filosófica. Tem uma unidade, as faixas vão se completando, caminhando em torno de uma ideia central" (Frans Elton, Raul Seixas. A história que não foi contada, p. 106). Em suas músicas, o pessimismo schopenhauereano, o niilismo nietzscheano e o existencialismo sartreano se fazem presentes de maneiras às vezes irônicas ${ }^{12}$.

Tentando ir mais diretamente ao ponto central, sustentarei que Seixas se engana quando traça essa dicotomia cortante entre "escrever" (um tratado) e "fazer música", pensando que num determinado momento da sua vida ele "abandona" a ideia de ser escritor para passar a ser músico. Não digo isto pensando que, afinal de contas, letras de canções podem ser também consideradas literatura (e até merecer um Prêmio Nobel!). Penso num autoengano mais profundo. É que as ideias filosóficas não estão, de início, hipotecadas por nenhuma forma específica de exposição, elas não são, por si sós, escritura, filmagem, dança ou o que for. As ideias filosóficas não estão comprometidas com a escrita tal como nos vem da tradição filosófica europeia ${ }^{13}$. Ideias filosóficas podem ser 
expressas em forma escrita, em forma de dança, de música ou de imagens de cinema. É uma casualidade histórica que a tradição filosófica tenha se consolidado sob a forma literária. Ao optar pelo meio musical, Seixas não "abandonou" a ideia de ser um escritor filosófico ou de escrever um tratado de metafísica; apenas mudou a forma em que essas ideias iriam ser transmitidas. Podemos aceitar que o tumultuado conjunto dos shows e LPs de Raul Seixas constitua, precisamente, seu tratado de metafísica. E, mais ainda, que a forma de vida (e de morte) dentro da qual essas expressões se manifestaram faz parte dessa produção filosófica.

Tentemos entender melhor as ideias-mestras da metafísica raulseixista. Eu me arrisco a apresentar as seguintes como sendo as fundamentais: (1) Os humanos procuram por verdades absolutas e permanentes; mas as verdades são todas individuais, e cada um deve vivê-las e representá-las em sua própria experiência com autenticidade, sinceridade e total envolvimento (em seu caso, isso era o que ele gostava de chamar o "raulseixismo"); (b) Isto torna os humanos, ou deveria torná-los, em metamorfoses ambulantes, no sentido de seres que mudam permanentemente, que não se fixam em nada, e que estão habilitados para sustentar ideias diferentes e mesmo contraditórias no percurso de suas vidas, talvez dentro de um mesmo dia; (c) Isto não leva a um individualismo fechado, mas a uma espécie de "personalismo egoísta" a partir do qual podem irradiar atitudes e condutas que beneficiam outras pessoas (o egoísmo extremo consiste em ajudar); (d) Não se deve, pois, aderir a um assistencialismo piedoso, mas tentar ser forte e predominar sobre os outros, divulgando as próprias verdades individuais de forma convicta, mas de 
modo a deixar as pessoas livres para fazerem as suas próprias escolhas; (e) Não há, pois, nenhuma verdade universal e absoluta que possa ser pregada aos outros a partir de algum lugar ou de alguma mente privilegiada; nem sequer isto mesmo; (f) Com efeito, esta filosofia aberta e metamórfica pode também mudar, aplicar-se a si mesma, e transformarse, inclusive, no contrário, em desejo de uma vida estável e segura, como parte do mesmo vaivém em que as vidas humanas consistem.

Vejamos alguns textos que ilustram estas ideias. "No seu álbum de 1974, Gita, Raul parecia um profeta maluco; tentando convencer a humanidade das excelências de sua nova concepção histórico-filosófico-esotérica” (RS, p. 29). “E de repente descobri que a luz, o conhecimento, tem de vir de você mesmo. (...) (Gita) é um disco doutrinário. Já reparou na capa? Estou eu lá, de dedo para cima, veja se é possível! Como se eu quisesse indicar caminhos para as pessoas" (p. 31). Acerca da "sociedade alternativa", ele escreve: "Cada um que faça a sua. Não vou ser mais guru de ninguém. Já estive numa posição assim. Não quero. Não estou mais preocupado em fazer o 'Novo Aeon' chegar, mudar as coisas..." (p. 33, p. 133) (Sonielson Silva, Raul Seixas e a Modernidade (RM), p. 82). "É um movimento individual meu. Não é juventude transviada nem hipismo; é raulseixismo" (RS, 56). "Acontece que minha linha agora é o egoísmo, o raulseixismo. Tenho meus próprios valores, sou meu próprio país" (104). "Eu sou uma pessoa que vive em 1976. Eu sou Raul Seixas, o único. (...) Eu sou fruto da pós-guerra. Sou um cara cheio de influências. Eu sou Raul Seixas" (p. 109).

Em sua monografia de mestrado sobre Raul Seixas, Vitor Santos escreve: “A mudança não seria para uma nova 
FILOSOFAR ACADÊMICO E PENSAMENTO INSURGENTE: (DIS-PENSANDO A FILOSOFIA...

ordem social, um novo Estado, como defendem as diversas correntes socialistas e comunistas. Raul apregoa uma Sociedade Alternativa dentro de cada individuo, de acordo com a própria vontade. Nos dizeres do compositor: 'Recebo cartas e mais cartas toda semana, gente querendo aderir ao projeto. Mas quero avisar que a Sociedade Alternativa não é um clube ou um partido, é uma ideia. A carteirinha do clube é você mesmo. É a sua cabeça" (Santos V. Novo Aeón: Raul Seixas no torvelinho de seu tempo, p. 71). "O egoísmo (...) privilegia o eu em detrimento do processo de massificação (...)Este solipsismo (...) possui traços progressistas, por valorizar a autonomia, mas também é conservador, por defender que nenhuma exigência deve ultrapassar os limites do ego. (...) Nas palavras de Raul: 'O novo Aeon foi um movimento particularmente meu e por isso tem aquela música, Eu sou egoísta. Eu acho que o individualismo é muito mais sincero do que as preocupações com a coletividade" (Id, p. 87. Ver também p. 63, p. 85) ${ }^{14}$.

Mas é importante frisar que este mesmo pensamento metamórfico ambulante pode ser mudado, e, como diz a letra "Vou desdizer aquilo tudo que eu thes disse antes". "...é necessário força para suportar e ousar ser uma metamorfose ambulante, abandonando o repouso servil de seguir a vontade de outrem" (Idem, p. 72). "Pode parecer incoerente a princípio, mas o contraditório seria afirmar que uma vez escolhido viver em transformação não se pudesse desistir disso e desejar uma vida estável" (Devides D, "Raul Seixas: um livre-pensador", em: Raul Seixas. Estudos interdisciplinares, p. 34-35) ${ }^{15}$. Isto significa que a tese da verdade ser única e individual e de não haver verdades absolutas se aplica a si mesma, não se refutando, mas, pelo contrário, confirmando-se; pois uma 
metamorfose ambulante pode perfeitamente decidir deixar de ser uma metamorfose ambulante e viver de uma maneira quieta e fixa; mas isto será uma escolha e não um destino.

Todos estes pensamentos constituem realmente uma metafísica num sentido bastante abstrato. Não é, por exemplo, uma "política", apesar dos críticos e público em geral sobretudo das classes médias - tentarem atribuir-lhe algum tipo de orientação política definida. Mas, precisamente, por ser o humano - na antropologia raulseixista - uma metamorfose ambulante, isso o afasta de qualquer postura política fixa e absoluta ou de qualquer engajamento partidário. "Não acredito em verdades absolutas, e isso implica a anulação da política" (RS, p. 78). Como era óbvio que suas músicas transmitiam críticas sociais, Seixas era facilmente filiado como "cantor de protesto", algo ao qual ele reagiu inclusive escrevendo músicas alusivas (como "Eu também vou reclamar"). Mas ele nunca foi, por exemplo, um militante de esquerda, como outros cantores intelectuais (inclusive baianos), nem um coletivista, mas alguém que reagia veementemente contra toda e qualquer forma de imposição autoritária, contra toda e qualquer suposta verdade absoluta, contra qualquer forma de censura; reivindicando espaços para manifestar a própria individualidade da maneira como cada qual a sentia. Era um individualismo a partir do qual se esperava irradiar algo de positivo para os outros, mas sem qualquer tipo de vocação assistencial ou salvadora.

Tampouco defendia nenhuma "causa latino-americana", e debochava de qualquer alusão a "raízes". "Não existe rock brasileiro (...) Essa história de procurar raízes é uma bobagem. As únicas raízes que eu conheço são de amendoim e mandioca" 
FILOSOFAR ACADÊMICO E PENSAMENTO INSURGENTE: (DIS-PENSANDO A FILOSOFIA...

(RS, p. 111). “Eu não estou me queixando de nada porque eu não sou um rapaz latino-americano; esse regionalismo não está em mim. Eu sou Raul Seixas, o único. Eu não pertenço a qualquer grupo político ou regional" (Silva Sonielson. RM $\mathrm{R}_{2}$ p. 41-42). Era admirador ferrenho dos Estados Unidos em matéria de música e cantou muito em inglês. “(...) Raul Seixas, no início da sua carreira, foi considerado alienado, entreguista e adepto aos ideais norte-americanos por não incluir assuntos políticos em suas letras, como fazia a maior parte dos artistas da MPB e do Tropicalismo". (Dos Santos, Paulo. A mosca na sopa da ditadura militar, p. 28-29).

Por outro lado, acreditava na filosofia nietzscheana do homem forte: "O povo sempre foi povo, sempre foi liderado (...) Porque sempre existiu povo e quem sempre mandou no povo desde os primórdios da história foi uma elite" (RM, p. 42). "Quem é forte, é forte e dá porrada. Você vai se lamentar? Se você é mais fraco, dane-se! Isso pode parecer nazismo, mas, se você é fraco e não quer levar porrada, fique forte e passe a dar. É Hitler mesmo!" (RS, 111). "Eu estou sentindo que nesse momento até a Terceira Guerra Mundial eu curtiria. A coisa não pode ficar nesse marasmo total" (RS, 123), declarações que poderiam considerar-se como um pedaço de pensamento "de direita".

$\mathrm{Na}$ verdade, a sua postura política era precisamente aquela compatível com a sua metafísica do individuo único, uma política libertária e antiautoritária, do lado que fosse. (Devides D, "Raul Seixas: um livre-pensador", em: Estudos Interdisciplinares, p. 31). E também profundamente criativa, autocriativa (de criar-se a si mesmo) e vital: melhor destruir e se autodestruir do que ficar numa expectativa medíocre e 
quietista, ou num protesto social lamurioso. Com esta atitude, ele conseguiu irritar tanto a "direita" quanto a "esquerda" (RS, p. 159), e ser finalmente considerado um "anarquista" (p. 123; Devides, op.cit. em: Raul Seixas. Estudos interdisciplinares, p. 37), ou alguém sem proposta política definida. Talvez o traço mais marcante desta metafísica raulseixista seja a autenticidade radical com que pretendia ser assumida numa forma de viver e de criar, algo que o liga com tantos e tantos outros compositores e músicos como Bob Dylan, Mick Jagger, Bob Marley, etc. Todos eles assumiram a criação musical, com sua carga filosófica mais ou menos marcada, como algo fortemente pessoal que não se deixa explicar nem colocar em palavras, experiência extrema que passa a ser desvirtuada quando se tenta falar sobre ela, como acontece habitualmente em entrevistas, onde os jornalistas querem dissecar tudo ${ }^{16}$.

Na metafísica raulseixista, há uma verdade individual que aparece nas músicas e que não poderia ser explicada mediante universais, precisamente por surgir de um individuo único em circunstâncias únicas. “...a arte é o espelho social de uma época, de um momento. Então, não existe arte, e sim a própria pessoa se expressando" (Santos Vitor, Novo Aeon: Raul Seixas no torvelinho de seu tempo, p. 7). "Porque eu não vejo a música como arte. Música é apenas a vomitada de cada pessoa. Uma cusparada. É a expressão de cada um" (Id, p. 133). Mas é precisamente por isso que ele não "abandonou", em nenhum momento, a sua intenção de fazer uma metafísica; apenas desistiu de escrevê-la em forma de tratado.

Esta metafísica leva diretamente à ideia de Raul Seixas como via de insurgência contra a exigência de frieza vital da filosofia, tal como recomendada nas academias explicitamente 
criticadas por Seixas (e ele sabia do que estava falando, pois passou por elas e obteve facilmente seu "diploma de filósofo"). Aqui o pensamento filosófico chega a seu máximo extremo de apropriação vital. Essa filosofia não se resume nas letras das canções (algumas delas extremamente ricas em pensamentos, como "A maçâ", "Canto para minha morte" e "Gospel"), tal como muitos estudiosos acadêmicos estão fazendo atualmente, estudando o "conteúdo filosófico" das letras. Isto também é importante, mas não é para mim o essencial. A questão crucial é que esses conteúdos - sejam quais forem e independentemente de sua qualidade ou originalidade foram totalmente incorporados ao ato do cantar, dançar, mover-se e executar toda a performance de shows e gravações. É filosofia em movimento, abrangendo não apenas o cantor, mas o público - real e virtual - e o ambiente todo. Aqui a filosofia não está presente apenas no que está sendo cantado ou gritado, mas na atitude de "exposição" (no duplo sentido de expor e de "expor-se", algo que, às vezes, Raul não conseguia fazer: enfrentar o público).

Ao contrário do scholar universitário, que afundou a totalidade da sua vida na escrita erudita, a filosofia de Raul Seixas faz o movimento inverso: mergulha o pensamento na experiência mais rica e mais quente, na qual as ideias filosóficas são totalmente transformadas em música, dança e atuação. Enquanto os comentadores eruditos deixam que a sua escrita absorva a totalidade da sua biografia pessoal, de tal forma que esta desaparece em seus escritos, crivados de citações e referências, Seixas deixa que todo seu pensamento seja sugado pela vida, de tal forma que a filosofia explícita (seu almejado "tratado de metafísica") simplesmente desaparece 
em beneficio do performático e vivido. Enquanto ele faz vida sem filosofia (no sentido de filosofia totalmente mergulhada na vida), os scholars fazem filosofia sem vida, pensamento que suprimiu totalmente suas raízes existenciais. Não quero sugerir - como o fazem alguns de seus comentadores - que as letras das canções de Seixas sejam alta filosofia. Por mais filosóficas que sejam algumas de suas letras, o que é filosófico em seu mais alto grau é a sua atitude de radical consumação do próprio pensamento numa suprema forma de criação e autocriação, que se manifesta, inclusive, em suas canções mais comerciais e menos ricas conceitualmente.

Raul Seixas viveu e morreu a letra de suas canções, e isso é mais fundamental do que essas letras. Ele não estava brincando ou fazendo meros jogos intelectuais; estava tentando entender e suportar a vida, dar-lhe um sentido e deixar a sua marca, como ele tantas vezes o manifestou: "Quero sair na História, ser lembrado. Porque tem gente que morre e gente que não morre" (RS, p. 119). "Com aquela segurança de que você nasceu para grudar sua impressão digital neste planeta” (p. 133). Ele viveu o vazio alienado da vida "normal" ("Ouro de tolo", “"É fim do mês", "Maluco beleza"), a tentativa heroica e sofrida de superar esse vazio ("Tente outra vez", "Faça, fuce, force", "Rockixe"), de driblar as armadilhas das relações humanas e os casamentos, ao mesmo tempo acolhedores e castradores ("Medo da chuva", "A maçâ") e das drogas ("Check up"); viveu a resistência política ("Aluga-se", "Abre-te Sésamo"), a crítica musical ("Eu também vou reclamar", "A verdade sobre a nostalgia", "As aventuras de RS na cidade de Thor"), o oscilar entre a tentação das verdades absolutas e as verdades individuais ("'Let me sing, let me sing", "Gita", "Sociedade 
alternativa", "Metamorfose ambulante", "Carpinteiro do universo") e a morte ("Canto para minha morte" e "É fim do mês", onde ele diz que já pode morrer em paz porque acabou de pagar a última prestação do seu "tumbão").

Mas um filosofar que mergulha totalmente numa forma de vida também constitui uma forma de morte. A autenticidade mortal de um filosofar cantado e dançado, muitas vezes vociferado, a atitude de não se apresentar despreparado diante do público, a necessidade de se estimular artificialmente para poder arcar com o tremendo esforço dos shows, a desistência de muitos shows por não acharse em condições físicas, o excesso de drogas e álcool, seus casamentos tumultuados e relações complicadas, todo esse pensamento feito pele fez com que o pensador não pudesse carregar essa metafísica vivida além de escassos e sofridos 44 anos. As últimas imagens de Seixas cantando heroicamente ao lado de Marcelo Nova o mostram definhando de depressão, sem qualquer possibilidade de enfrentar a velhice, sem forças para "tentar outra vez", literalmente derrubado pelas verdades que descobriu sobre a vida. Mas um pensador capaz de morrer pelos seus pensamentos era, precisamente, o que Nietzsche pedia de um autêntico filósofo, e que não encontrava nas academias.

Oswald de Andrade e Raul Seixas são dois dispensadores brasileiros natos que desafiaram características irrenunciáveis do filosofar acadêmico (a exaustividade, a frieza objetiva), obediente às ideias do Acervo T. Ambos foram artistas que mostraram como a arte pode ser metafísica na sua forma de execução, sem necessidade de qualquer tipo de transcrição ou tradução. E ambos estavam muito próximos em muitos 
pontos. Se poderia dizer que Oswald foi um raulseixista e que Seixas foi um oswaldiano. No "Manifesto antropófago" há frases que são totalmente raulseixistas: "Contra todos os importadores de consciência enlatada", "Contra o mundo reversivel e as ideias objetivadas. Cadaverizadas. O stop do pensamento que é dinâmico. O indivíduo vítima do sistema. Fonte das injustiças clássicas. Das injustiças românticas. E o esquecimento das conquistas interiores". Por seu lado, Raul Seixas fez com a filosofia e com os filósofos (Schopenhauer, Nietzsche, Sartre) exatamente uma devoração oswaldiana, selecionando pensamentos e frases isoladas destes pensadores, apenas aqueles que interessavam para compor suas músicas, sem qualquer intuito de entendê-los de maneira exaustiva, tal como lhe ensinaram, sem dúvida, na universidade, quando se formou em filosofia. Assim, certamente Oswald aceitaria a ideia raulseixista do homem como metamorfose ambulante, e Raul aceitaria que a vida e a arte são fundamentalmente fragmentárias. As suas metafísicas confluem de maneira admirável, mas nada surpreendente, já que ambos respiram fundamentalmente na mesma atmosfera de amor à criatividade e de desprezo por todas as imposições externas contra o pleno desenvolvimento da vida do pensamento.

\section{RESIGNIFICANDO “EUROPA". POLÍTICAS INSURGENTES E INDÚSTRIA CULTURAL FILOSÓFICA.}

A maneira de fazer filosofia guiada pelo Acervo $\mathrm{T}$ e seus desdobramentos estabeleceu um específico tipo de relação com o pensamento europeu. Em princípio, poderíamos 
identificar pelo menos duas maneiras diferentes de receber o legado filosófico europeu: (1) Expor e difundir o pensamento gerado na Europa. (2) Assumir a atitude criativa e autoral dos pensadores europeus ao construírem suas filosofias. Na opção (1), Europa nos lega uma filosofia como objeto de estudo; na alternativa (2), Europa nos lega uma atitude. Assumindo a primeira alternativa, reapresentamos os conteúdos da filosofia europeia; assumindo a segunda, tentamos fazer filosofia como os pensadores europeus fizeram as deles.

Parece bastante claro que, no atual contexto institucionalizado da filosofia, é a opção (1) a que foi adotada. Já em outro texto meu anterior ${ }^{17}$, eu chamei a atenção sobre uma curiosidade desta opção, que se poderia resumir na seguinte norma paradoxal: "Estude a filosofia feita pelos pensadores europeus, mas não faça filosofia como eles". Explique-os o mais exaustivamente possível, mas não os siga em seus próprios gestos reflexivos. Estude textos que você considera extraordinários, mas nunca tente escrever um texto extraordinário. A opção (1) nos impede considerar os pensadores europeus como mestres e nos obriga a considerálos como objetos de contemplação, estudo e culto. O que Europa forneceria nesse caso seria uma longa agenda de "problemas filosóficos" a serem devidamente estudados, enquanto que, na alternativa (2), nada impediria focar conteúdos completamente diferentes dos apresentados na história oficial da filosofia, mantendo a atitude que os pensadores europeus assumiram a respeito de suas próprias temáticas. É claro que a poderosa força política do Acervo T quer nos convencer de que Europa não colocou problemas próprios, mas problemas "universais" para toda a humanidade. Em "Europeu não significa universal, 
brasileiro não significa nacional...", já mostrei que existe uma longa lista de problemas filosóficos, de interesse da humanidade, que não foram colocados pela tradição europeia de pensamento (e muitos deles nem poderiam ser colocados por essa tradição).

Se a nossa maneira de receber o legado europeu for guiada pela opção (2) - a herança de uma atitude - em seguida salta aos olhos algo muito curioso: as exigências de exaustividade e frieza vital nunca caracterizaram o estilo europeu de filosofar. Os considerados pelo establishment como "grandes filósofos" jamais foram leitores exaustivos e cuidadosos de seus predecessores, nem deixaram de se envolver vital e biograficamente com o que escreviam (e muitos deles, como Agostinho, Abelardo, Descartes, Rousseau e Nietzsche, foram inclusive autores de autobiografias). Especificamente no período moderno, filósofos europeus como Descartes, Kant, Hegel, Schopenhauer, Nietzsche e Heidegger, entre muitos outros, fizeram leituras funcionais dos outros filósofos muitas vezes rápidas e pouco cuidadosas - e acentuaram veementemente o caráter pessoal e comprometido do ato de pensar.

É fácil ver que a maneira (1) de receber o legado europeu vai inicialmente contra o recomendado e assumido pelos próprios filósofos europeus: uma filosofia expositiva e repetitiva, norteada pelo Acervo T e pelas duas exigências, não fará, por exemplo, um uso autônomo do próprio bom senso (Descartes), não entrará no estágio do "esclarecimento" e na maioridade de idade no sentido de livrar-se da tutela do outro (Kant); não desenvolverá conceitos na própria historicidade da reflexão (Hegel), não evitará a maneira livresca de abordar 
FILOSOFAR ACADÊMICO E PENSAMENTO INSURGENTE: (DIS-PENSANDO A FILOSOFIA...

problemas, deixando de incentivar a intuição mesma do mundo (Schopenhauer), nem responderá ao chamado do Ser de maneira responsável e comprometida (Heidegger).

$\mathrm{O}$ Acervo $\mathrm{T}$ e seus desdobramentos normativos estabelecem um particular tipo de relação com "Europa". Mas se ousarmos desafiar essas ideias hegemônicas, começaremos a visualizar outras maneiras de fazer filosofia e de pensar a relação com o pensamento europeu. Isto é, precisamente, o que eu chamo "dispensar Europa": não descartá-la (o que seria impossível e indesejável), mas pensá-la na contramão, retomá-la num viés totalmente diferente. E, precisamente, os nossos dois dispensadores insurgentes - Oswald de Andrade e Raul Seixas - fornecem dicas preciosas para começar a tentar nos desvencilhar do poderoso predomínio do Acervo $\mathrm{T}$ e da maneira de vincular-nos com o pensamento europeu que ele impõe. Entretanto, a adoção da alternativa (2) de recepção do legado europeu está, a meu ver, bloqueada não porque, como se diz, o latino-americano não tenha "cabeça filosófica", nem pelas insuficiências da sua interminável "formação". Os próprios pensadores europeus nos fornecem elementos para derrubar estas fracas hipóteses. Não; esse caminho está bloqueado pelo próprio sistema que organiza os estudos filosóficos em nossos países, ao manter vigentes as normas (1)-(7) do Acervo T e seus desdobramentos normativos, num ambiente dominado por uma espécie de indústria cultural filosófica.

Adorno e Horkheimer criaram a expressão "indústria cultural"18. Aplicam esse conceito, sobretudo, nas artes e na literatura, e nos chamados espetáculos de massas, como o cinema e a TV. Adorno apresenta vivamente as características 
mais típicas da indústria cultural: a padronização e a semelhança dos produtos culturais, que os torna facilmente consumíveis; a especialização em setores assinalados, com seus respectivos públicos e mercados; o predomínio do aperfeiçoamento tecnológico sobre a qualidade; as maneiras rápidas e eficazes de transmitir informações, e a crescente rapidez de seu consumo; a homogeneidade dos produtos, que torna inesencial mudar de canal; a padronização dos próprios consumidores e a inércia na recepção; o valor de mercado dos produtos além de sua qualidade e a dificuldade de encontrar produtos que fogem do estabelecido e padronizado.

A indústria cultural gera uma aparência de concorrência e ampla possibilidade de escolha dentro do sempre igual e homogêneo; a previsibilidade dos desfechos (de filmes, por exemplo) para o público não ser desagradavelmente surpreso; o consumo dos produtos se torna algo distraído e automático, no meio do fantasma do tédio e do vazio de consumo; buscase o divertimento e a distração; a produção se transforma em trabalho repetitivo, longe do criativo e crítico; aparecem o estrelismo e as feiras de vaidades dos grandes favorecidos pelo sistema; a indústria cultural oferece muito, mas sem nunca satisfazer plenamente; cria, guia e disciplina os desejos dos consumidores; impõe uma linguagem, jargões apropriados para os diversos cenários da indústria cultural; a necessidade permanente de novos efeitos, de impressionar, de apresentar algo novo; e uma poderosa capacidade de exclusão daquilo que é produzido fora dos padrões.

A filosofia sempre pareceu pairar por cima da indústria cultural, gozando de suficiente autoridade moral para criticála. Os próprios autores do termo utilizaram a filosofia como 
instrumento crítico da indústria cultural. Mas na sua atual configuração acadêmica - norteada pelo Acervo $\mathrm{T}$ e pela maneira (1) de se apropriar do legado europeu - a filosofia não aparece tão livre quanto desejaria das armadilhas da indústria cultural. Atualmente, nas universidades, estimulase fervorosamente a produção intelectual em série (sobretudo de papers), e os profissionais da filosofia são severamente avaliados em função da quantidade de papers que conseguem produzir por ano; disso dependerá seu sucesso em concursos, seleções, progressões funcionais e admissão como conferencistas em congressos. Os papers são fortemente padronizados, inclusive, pelas revistas especializadas melhor avaliadas, com regras e linguagens muito precisas, regras não meramente "formais" já que impõem sutilmente conteúdos; qualquer estilo mais autoral ou desregrado será chamado à ordem por algum parecerista, em geral em forma de indicações sumárias, porque na indústria cultural filosófica todo mundo está sempre "muito ocupado".

Os papers filosóficos têm seu próprio mercado de consumo, o que os torna visualizáveis e consumíveis por parte de uma clientela específica; a "tecnologia do texto" (como poderíamos chama-la) se tornou prioritária, e ideias interessantes ou importantes poderão ser rejeitadas pela forma, por não se adequarem às modernas técnicas expositivas da filosofia. As informações transmitidas pelos papers aparecem como muito variadas, porém, se lidas com cuidado, são espantosamente reiterativas; papers de ou sobre afamadas figuras da filosofia europeia - as grandes "estrelas" - terão prioridade e serão mais lidos do que papers de desconhecidos pensadores caribenhos ou africanos; quando um autor se torna consagrado, 
vira inacessível como um ator de cinema. Os papers serão considerados "de qualidade", segundo severos padrões de avaliação partilhados pelas comunidades de especialistas, que excluem o que não se enquadra dentro deles e portanto não será vendido (ou será rejeitado pelo público se for editado).

O consumo de papers, assim como o assistir a palestras em congressos, torna-se uma prática monótona e rotineira, em grande medida um "divertimento cultural" distraído, e os participantes vão depois comentar, decepcionados, que não ouviram "nada de novo" nas apresentações. Embora a filosofia acadêmica continue gostando de ver-se como "perigosa para o sistema" ou como ameaçadora para tiranias e autoritarismos, há muito tempo que ela já se transformou numa parte funcional desse mesmo sistema e gerou suas próprias formas de autoritarismo, na medida em que tem algo para vender e compradores cativos; o pensar se tornou uma carreira bem sucedida, em virtude da qual os profissionais e especialistas em filosofia erguem um prestígio, potenciam uma especialização e passam uma boa porção das suas vidas viajando pelo mundo.

As atividades filosóficas entendidas segundo o Acervo $\mathrm{T}$ e seus desdobramentos normativos, e segundo a maneira (1) de receptar o legado europeu, são precisamente aquelas que a indústria cultural filosófica estimula e das quais se retroalimenta. $\mathrm{Na}$ situação atual, rebelar-se contra esta maneira hegemônica de conceber as atividades filosóficas é uma empreitada insurgente marcadamente quixotesca ${ }^{19}$. Este esforço constituirá um ato de resistência intelectual, tentando promover mudanças profundas nas maneiras usuais de ler, escrever, pesquisar e ensinar. Este pensamento insurgente é 
eminentemente político, não num sentido partidário, de um "tomar posição" (aquilo que se exigia de Raul Seixas e que ele não conseguia preencher, deixando todo mundo descontente), mas no sentido do abalo de pensamentos estabelecidos, tais como os pensamentos da exaustividade e do pensamento frio e distanciado. A ideia da insurgência é, precisamente, que os dominados só podem desenvolver-se como pensadores e criar ideias filosóficas em estado de insurgência, o que os transforma, precisamente, em dispensadores, não das filosofias herdadas, mas de um tipo de relação dependente e reiterativa com elas, o que impede apoderar-se criativamente do grande legado europeu.

Algo semelhante deveria ser dito sobre o debatido tema da “originalidade" de um pensamento filosófico. Uma produção filosófica latino-americana, não guiada pelas exigências de exaustividade e frieza vital, que seja seletiva e biográfica, aparecerá - dentro do euro-centrismo vigente - como "de baixa qualidade", mal fundamentada, "meramente narrativa" e longe de qualquer "contribuição relevante" à história da filosofia. Deve ser óbvio que dentro do raio de influência de uma política insurgente toda a questão da "originalidade" deverá ser repensada. O "original” não pode ser visto como uma "contribuição" nova às agendas hegemônicas, mas como ruptura insurgente do estabelecido em direção a um pensar situado. Focar a questão da originalidade em termos de "contribuição" implica ainda vincular o original a uma questão de essência, enquanto que, dentro da insurgência, a originalidade assinala para uma questão de existência, de vir a ser. $\mathrm{O}$ pensamento latino-americano será original na insurgência e no dispensar, ou não será. 
Dentro da indústria cultural filosófica, as filosofias ganham um valor de mercado. Numa comunidade filosófica norteada pelas normas do Acervo $\mathrm{T}$ e seus desdobramentos é o valor das filosofias europeias aquele que aumenta mais e mais a cada dia, enquanto o valor dos pensadores nacionais vai para uma queda irreversível. Em tempos desconstrucionistas e deflacionários como os nossos, não acreditamos mais na categoria de "gênio" do Idealismo alemão, nem pensamos em valores num sentido objetivo. O "grande valor" da filosofia europeia e a "falta de valor" do pensamento de países latinoamericanos e africanos não é algo "dado", mas produto de procedimentos, estratégias e lutas políticas; não surge das entranhas mesmas da terra. Num contexto pós-metafísico, algo não é apreciado por ser valioso, mas vai tornando-se valioso à medida que for mais e mais apreciado.

Imagine por um momento o que poderiam significar os escritos de Leibniz para um grupo tupi-guarani. Assim como os colonizadores europeus - como aponta Oswald de Andrade - não encontraram Cristo já sendo adorado em América pelas tribos indígenas, tampouco encontraram os valores que determinam a genialidade de Leibniz, dependentes de um treinamento cultural no qual os tupis não tinham sido submetidos. (O mesmo aconteceu com os conquistadores, mesmo cultos, diante das culturas indígenas; estas não eram "bárbaras", apenas respondiam a treinamentos que os europeus não tinham recebido). Por outro lado, um pensador como Tobias Barreto, para tomar um exemplo, não é um filósofo "sem valor" porque assim o constatem "objetivamente" os especialistas, mas a atitude destes especialistas contribui para construir historicamente a "falta de valor" de Tobias Barreto como pensador dentro do mercado de ideias. 


\section{PALAVRAS FINAIS, FRAGMENTÁRIAS E AMBULANTES}

Há uma incongruência entre a expectativa de filosofia original e criativa, por um lado, e a sujeição das atividades filosóficas ao Acervo $\mathrm{T}$ e seus desdobramentos, pelo outro. Uma dessas duas coisas deverá ser abandonada. Uma comunidade filosófica realmente plural e democrática teria que permitir que, em suas universidades, também se pudesse fazer filosofia da maneira como Oswald de Andrade e Raul Seixas a assumiram, de maneira fragmentária e vitalmente comprometida. Isto não é o mesmo, evidentemente, que ficar escrevendo dissertações e teses sobre estes dois autores, mas ser capaz de assumir as suas atitudes dispensantes. Os casos de Raul e Oswald nos fazem ver que nestes tempos de pensamento domesticado a arte popular e de massas, como o cinema e a música, pode ser lúcida, e o pensamento filosófico institucionalizado pode ser alienado.

\section{NOTAS}

${ }^{1}$ Professor aposentado da Universidade de Brasília (Unb). Doutor em Filosofia pela Universidade Nacional de Córdoba (Argentina). E-mail: kabra7@gmail.com.

2 "Europeu não significa universal; brasileiro não significa nacional" (2015).

${ }^{3}$ A diferença entre países latino-americanos a respeito disto reside em que, em alguns deles, como o Brasil, as atividades filosóficas se identificam sem resíduos com o filosofar norteado pelas ideias do Acervo T, enquanto em outros países latino-americanos, como Colômbia, por exemplo, uma parte da filosofia responde ao Acervo T, mas ainda são praticadas atividades 
filosóficas alternativas que são acompanhadas e respeitadas por boa parte da comunidade filosófica. (Ver Pachón Soto Damián, Estudios sobre el pensamiento colombiano. Volumen I, Ed. Desde abajo, Bogotá, 2011. pp.125-129).

${ }^{4}$ Curiosamente, o autor mencionado por último, John Searle, quebrou, de certa forma, essa norma. Na Introdução de seu livro "Intencionalidade", de 1983, ele escreve: "Parte do prazer em se escrever sobre os atos de fala está em não haver nenhuma tradição filosófica de envergadura a sujeitar a investigação (...)No tocante à Intencionalidade, porém, a situação é bem diferente. Movimentos filosóficos inteiros foram construídos em torno de teorias da Intencionalidade. O que se pode fazer perante todo esse eminente passado? Minha atitude pessoal tem sido a de simplesmente ignorá-lo (...)" Searle, Intencionalidade, Martins Fontes, 1995, XI). É claro que Searle desafiou a "exigência de exaustividade" no que tange à tradição filosófica (em grande parte, "continental"), mas certamente ele está perfeitamente "atualizado" a respeito de tudo o que se escreve sobre estes assuntos na tradição analítica à qual ele pertence. Entretanto, pelos motivos que serão aludidos na seção 3 deste trabalho, pensadores norte-americanos adquiriram poder político como para ignorar tradições, poder que pensadores paraguaios não teriam. Estes são severamente submetidos à "exigência de exaustividade".

${ }^{5}$ Cfr. Schopenhauer A., "Sobre a filosofia universitária", "Sobre a erudição e os eruditos" e "Pensar por si mesmo", todos incluídos em "Parerga e Paralipomena”. (Ver Cabrera J, Diário de um filósofo no Brasil, 2013 (2a edição), pp. 216-218).

${ }^{6}$ Tomo como exemplo pessoal meu "Projeto de Ética negativa", de 1989, livro escrito em aforismas, pouco argumentado e fortemente biográfico, que jamais foi levado a sério pelo establishment de professores universitários brasileiros, embora merecesse atenção por parte de numerosos alunos ao longo das décadas (houve trabalhos finais de graduação e dissertações de mestrado sobre as ideias desse livro). As ideias antinatalistas deste livro foram depois publicadas em livros e artigos na Espanha, México e Argentina, e com a tradução inglesa da "Crítica de la Moral Afirmativa" começam a ser discutidas também no ambiente de língua inglesa.

${ }^{7}$ Poderia dizer, ironicamente, que não pretendo ser exaustivo. 
${ }^{8}$ Cfr. "Influencia del descubrimiento de América en las ideas generales", de Francisco Romero. (Em: Romero F,_Filosofia de ayer y de hoy, Argos, Buenos Aires, 1947, pp. 209-223.

9 Cfr. "Imanência do inimigo", "Perspectivismo e multinaturalismo na América indígena" e "Xamanismo e sacrifício" (todos incluídos no livro $A$ Inconstância da alma selvagem)

${ }^{10}$ Sonielson Silva, autor do livro "Raul Seixas e a Modernidade", comenta a presença de numerosas ideias de Nietzsche nas músicas do compositor baiano. Mas “(...) é curioso como o nome do filósofo alemão praticamente não aparece na biografia de Raul Seixas" (p. 60). Aqui Seixas, o nosso próximo dispensador, devorou Nietzsche de maneira tão radical que já não precisa mais mencioná-lo.

${ }^{11}$ Os artistas costumam ser menos pudicos: Milan Kundera fala de uma "filosofia da merda" (sic) em "A insustentável leveza do ser". Buñuel filmou um grupo de burgueses defecando em torno de uma mesa em seu filme "O fantasma da liberdade". Wim Wenders fez defecar um de seus personagens diante das câmeras, no filme "No decurso do tempo". Mas também os escritores tiveram problemas com a cultura fecal: um dos grandes obstáculos que James Joyce enfrentou para publicar o "Ulisses" foi a parte onde Bloom defeca, e que os editores queriam retirar. Parece que os ocidentais têm algum obstáculo freudiano com o que é expelido pelos seus corpos ilustrados.

${ }^{12}$ Cfr. Devides Dilson, "Raul Seixas: um livre pensador", em: Raul Seixas. Estudos interdisciplinares, p. 29.

${ }^{13}$ Expressei essa ideia em meu livro Cine: 100 años de Filosofía (Gedisa, Barcelona, 2015, 2a edição), Introdução, pág. 16. A ideia principal é que a filosofia consiste em relacionar conceitos e a proposição escrita constitui apenas uma forma de estabelecer essa relação; as situações em filmes, por exemplo, oferecem outra forma de ligar conceitos. (Este livro foi traduzido ao português com o nome de O Cinema pensa, mas a segunda edição do original espanhol contém novo material).

${ }^{14}$ É notável como estas ideias do único são muito semelhantes às de Max Stirner em seu livro "O único e a sua propriedade" (1844), mas não vi qualquer referência ao autor alemão do século XIX na literatura sobre Raul Seixas consultada, nem consta que ele mesmo o tenha lido. 
15 Para mais elementos na compreensão do "raulseixismo", se pode consultar também o capítulo "Eu vou fazer o que eu gosto", do livro Raul Seixas e a Modernidade, de Sonielson Silva, pp. 107-112.

${ }^{16}$ Isto ficou jocosamente claro na famosa entrevista pública ao jovem Bob Dylan, quando o público queria encapsulá-lo como "voz de uma geração", "consciência da juventude americana" e coisas do gênero. Dylan declarou que nada tinha a ver com nada disso, que ele simplesmente compunha e cantava, e que as coisas foram acontecendo, como tudo acontece. Seixas certamente assinaria embaixo de tudo isso.

17 Cfr. "Melancholia: a filosofia no Brasil entre a extinção e a nova Alexandria", incluído na segunda edição do Diário de um filósofo no Brasil (2013), pp. 213-240.

${ }^{18}$ Adorno explicitamente reivindica a autoria deste termo: "Sobre esta ( $a$ indústria cultural), enquanto meio de domínio e de integração, foi escrito tanto desde que Horkheimer e eu introduzimos seu conceito há mais de vinte anos..." (Adorno T, “Tempo livre”, em: Adorno T. Indústria cultural e sociedade, p. 114).

${ }^{19}$ Considero o "Dom Quixote" de Cervantes o grande divisor de águas entre as culturas hispânica e lusitana, apontando para dois tipos diferentes de atitudes diante da colonização. Enquanto o hispânico é capaz de mergulhar de cabeça numa empreitada na qual não tem a menor chance de sucesso (como o Quixote arremetendo contra os moinhos de vento), o pragmático lusitano não entra em lutas que ele não pode ganhar. A luta contra o Acervo $\mathrm{T}$ e seus desdobramentos, totalmente incutidos nas comunidades filosóficas, é uma luta quase impossível, largamente inglória e cheia de obstáculos imensos. Só um espírito quixotesco pode empreendê-la. 
FILOSOFAR ACADÊMICO E PENSAMENTO INSURGENTE: (DIS-PENSANDO A FILOSOFIA...

\section{REFERÊNCIAS}

ABONIZIO Juliana, TEIXEIRA Rosana. Raul Seixas. Estudos interdisciplinares. Edufmt, Matto Grosso, 2015.

ADORNO Theodor. Indústria cultural e Sociedade. $5^{\mathrm{a}}$ Edição. Paz e Terra, SP, 2009.

CABRERA J. Diário de um filósofo no Brasil. 2a Edição. Ijuí: Editora Unijuí, 2013.

CABRERA J. "Europeu não significa universal, brasileiro não significa nacional (Acerca da expressão 'filosofar-desde')". Revista Nabuco, ano 1, 2014/2015, pp. 14-47. (Disponível em: http://repositorio.unb.br/handle/10482/18028).

CABRERA, Julio. Projeto de Ética negativa. Mandacarú, SP, 1989. (2a edição como A Ética e suas negações. Rocco, RJ, 2011).

CABRERA, Julio. Crítica de la Moral Afirmativa: una reflexión sobre nacimiento, muerte y valor de la vida. $2^{\text {a }}$ Edição. Gedisa, Barcelona, 2014.

CABRERA, Julio. Cine: 100 años de Filosofía. 2a Edição. Gedisa, Barcelona, 2015.

DE ANDRADE Oswald. A Utopia antropofágica. Editora Globo, SP, $2001\left(3^{a}\right)$.

DE ANDRADE Oswald. Estética e Política. Ed. Globo, SP, 2011 $\left(2^{\mathrm{a}}\right)$. 
FRANS Elton. Raúl Seixas. A história que não foi contada. Irmãos Vitale, SP, 2002.

LUCENA M. Raul Seixas. Filosofias, politicas e lutas. A verdade absoluta. Macbel, Oficina de Letras, SP, 2002.

ROMERO, Francisco. Filosofia de ayer y de hoy, Argos, Buenos Aires, 1947

SANTOS Paulo dos. Raul Seixas. A mosca na sopa da ditadura militar. Censura, tortura e exílio. Scortecci, SP, 2014.

SANTOS Vitor C. Novo Aeon: Raul Seixas no torvelinho de seu tempo. Dissertação de Mestrado. Universidade Federal de Espírito Santo, Vitória, 2009.

SOTO, Damian Pachón. Estudios sobre el pensamiento colombiano. Volumen I, Ed. Desde abajo, Bogotá, 2011.

SEIXAS Raul. Raul Seixas por ele mesmo. Martin Claret, SP, 2012.

SCHOPENHAUER A. Parerga y Paralipomena. Valdemar, Madrid, 2009.

SCHARFSTEIN Bem-Ami. Los filósofos y sus vidas. Para uma historia psicológica de la filosofía. Cátedra, Madrid, 1984.

SILVA Sonielson Juvino. Raul Seixas e a Modernidade. Uma viagem na contramão. Marca da Fantasia, João Pessoa, 2004.

VIVEIROS DE CASTRO Eduardo. A inconstância da alma selvagem. Cosacnaify, SP, 2011. 